\title{
Efficiency of banks in Slovakia: Measuring by DEA models
}

\author{
Eva Grmanová \\ Faculty of Social Economics Relationships, Alexander Dubcek. \\ University of Trencin, \\ Slovakia \\ eva.grmanova@tnuni.sk \\ Eva Ivanová \\ Faculty of Social Economics Relationships, Alexander Dubcek \\ University of Trencin, \\ Slovakia \\ eva.ivanova@tnuni.sk
}

Abstract. Stability of the financial system depends on the stability of its individual elements, banking system being the most important among them. In the today's competitive environment, Slovak banking sector consists of a large number of banks offering a wide range of services. For the banks operating in such environment it is not enough to distinguish themselves only through the parameters of products which are bringing short-term effects, but it is essential for them to build competitive advantage with some long-term perspective. The key contribution to a long-term strategy of any bank is assessment of its activities from the perspective of performance and efficiency. When analysing the actual situation, banks are trying to assess realistically their strengths and weaknesses regarding products, pricing, distribution, communication policy, bank management, organization structure etc. They assess their efficiency relative to other banks. For this purpose, banks use various methods seeking to find the most suitable combination of financial and non-financial assessment indicators. There are parametric and non-parametric methods for efficiency assessment. The most common method in the banking sector is the non-parametric method Data Envelopment Analysis (or DEA models). It allows analyzing the efficiency of transformation of multiple inputs into multiple outputs with the help of efficiency score. In the paper, DEA models were employed to assess the efficiency of Slovak banking sector. The three largest banks at Slovak national banking market were found to be efficient in both analysed years. Slovenská sporitel'ña, a.s. was efficient in all the models with different combinations of inputs and outputs.

Keywords: Data Envelopment Analysis (DEA), efficiency, banking system, commercial banks, Slovakia.

JEL Classification: C52, G21 


\section{INTRODUCTION}

In the competitive environment of today, Slovak banking sector covers a large number of banks offering a wide range of services. For banks operating within such environment it is not enough to distinguish themselves only through certain parameters of products which are able to bring short-terms effects, but it is essential for them to build competitive advantage with some long-term perspective. The key contribution to a long-term strategy of a bank is assessment of its activities from the perspective of performance and efficiency. A developed and efficiently functioning banking system facilitates the development of other business spheres within national economy and thus influences the development of the whole country (Ključnikov \& Popesko, 2017; Kubiszewska, 2017; Nuhiu et al., 2017).

As stated by (Knápková et al., 2014), new conditions of competitive environment require changes in measuring and managing economic indicators. The basic principle is a change from using purely financial indicators to setting broader spectrum of non-financial indicators.

Selection of indicators and their assessment are important aspects of financial management in a bank which is supposed to be in line with its strategic goals as to performance and efficiency as well as competitiveness with respect to the defined risks and regulated limits. Banks today are implementing the most advanced methods of risk management to their system and not just because of the new regulatory agreement (Cipovová \& Belás, 2012).

When analyzing its actual situation, a bank is trying to realistically assess its strengths and weaknesses in the areas of products, pricing, distribution, communication policy, management, organization structure etc. (Gąsiorowski, 2016; Puriwat \& Tripopsakul, 2017). For this purpose, a bank uses various methods and seeks to find the most suitable combination of financial and non-financial indicators to be used in the course of further assessment. There are parametric and non-parametric methods of efficiency assessment. The most common method in today's banking sector is the non-parametric method known as the Data Envelopment Analysis (or DEA models). These models allow analysing the efficiency of transformation of multiple inputs into multiple outputs with the help of efficiency score.

\section{LITERATURE REVIEW}

According to Berger \& Humprey (1997) the estimation of the efficiency of financial institutions has three main focuses of research and application options:

1 / It provides information on the effectiveness of government policies - for example when it comes to deregulation of the market or during mergers and acquisitions activities under the scope of anti-trust policies. It allows assessing the impact of market structure on the performance of specific sectors.

2/ It addresses research problems - such as changes in the efficiency score in the context of its assessment through different approaches, what factors influence the changes in the efficiency thresholds when analyzing financial institutions at different times.

3 / It assesses options for improving management performance - for example analyzing and comparing the efficiency of bank subsidiaries and identifying "the best" and "the worst" of the branches. It measures the efficiency score of financial institutions within one or more financial markets and thus allows evaluation of the policies and activities of financial institutions in several countries. The analysis of efficiency may be a part of the overall benchmarking of a specific financial institution.

DEA models are used to measure the efficiency of the country bank market but also to compare the efficiency of banks on individual markets. Vivas et al. (2002) compared the national banking markets of Belgium, Denmark, France, Germany, Italy, Luxembourg, the Netherlands, Portugal, Spain and the UK. The efficiency of banks is also compared for example by Chansarn (2008) in Thailand, Saha \& Ravisankar (2000) in India, Jemric' \& Vujčic' (2002) in Croatia, Luciano \& Regis (2007) in Italy.

Chansarn (2008) compared results gained from intermediation approach and operation approach. Commercial banks are more efficient via operation approach than via intermediation approach. Saha \& Ravisankar (2000) assess changes in efficiency. The public sector banks have in general improved their efficiency scores over the years 1992 to 1995. Jemric \& Vujčic (2002) compared old and new bank efficiency as well as their efficiency by size and ownership. The foreign-owned banks are the most efficient. The new banks are more efficient than old ones. The smaller banks are globally efficient. Luciano \& Regis (2007) 
compared banking groups and individual institutions efficiency. Individual institutions were found to be more efficient than banking groups.

Studies dealing with the efficiency of banks in Slovakia or the Czech Republic are comparing banks at national level (Jablonský \& Dlouhý, 2004) or in common banking market (Grmanová, 2010) respectively or within the V4 countries (Stavárek, 2005). Jablonský \& Dlouhý (2004) dealt with the possibilities of using MS Excel in assessing efficiency of 23 branches of a Czech bank through DEA models. The demonstrated the application of optimization solver in MS Excel. Having used the DEA models, Stavárek (2005) concluded that the Czech and Hungarian banking sectors were among the group of leaders. These sectors were followed by the Polish and Slovak banking sectors. Grmanová (2010) used DEA models to assess efficiency of Slovak and Czech banks in the common market of Slovakia and the Czech Republic. Of the Slovak banks examined, Slovenská sporitel'ňa, a.s. was found to be most efficient.

The choice of indicators used in analyzing the efficiency of banks varies. There have been three main approaches published on the selection of these indicators. Production approach was published for the first time by Sherman \& Gold (1985). The bank is considered mainly as a producer of deposit and loan accounts. The inputs are indicators of labor and capital. The output is the number of bank accounts or their financial value. Intermediation approach was published for the first time by Sealeay \& Lindley (1977). The approach assumes that the banks' main aim is to transform liabilities (deposits) into loans (assets). The bank collects deposits to transform them in loans (Palečková, 2015). The third approach is an approach in terms of assets. Output is measured as the total volume of lending and investment activities of the bank. The impact of the selection of indicators on the efficiency score is the subject of extended research. Wheelock \& Wilson (1995) are comparing the efficiency score results in 5 models, which use different combinations of inputs and outputs.

When analyzing the efficiency a lot of data is required, so the DEA models are often combined with multi-criteria methods, for example with Factor Analysis, Principal Components Analysis (PCA) and Cluster Analysis. In research, it is common to employ such methods that allow the reduction of the amount of data to be analysed. Combined application of DEA and PCA models in the banking sector was done by Kordostami et al. (2011). They analysed 25 branches of Iranian banks. The efficiency score was expressed by DEA model based on constant returns from the scale. Similarly Chandrasekaran \& Gopal (2013) are using PCA method of data reduction and consequently analyse the efficiency scores of banks.

Assessment of the possibility of improving management performance of banks was studied in the work by Cinca \& Molinero (2001). They applied a combination of DEA models as well as multi-criteria methods to express the efficiency score. PCA method was applied to measure the efficiency expressed in models with different combinations of inputs and outputs.

\section{RESEARCH GOAL, HYPOTHESIS AND METHODOLOGY}

The subjects of our analysis are banks in Slovakia. According to the NBS (2015) there were thirteen banks located in the Slovak Republic as of May 1, 2015. In contrast to the Czech Republic, in Slovakia the building societies are also classified as banks. To perform the efficiency analysis we have selected data from years 2009 and 2013. In 2009, the banking sector experienced the effects of financial crisis and the adoption of EUR currency. A four-year period of time represents a sufficient time difference for fixing the banking sector and at the same time it is important for the collection of data required for the analysis. The data for the analysis were drawn from annual reports (Banks, 2009), (Banks, 2013).

Previous research (Grmanová, 2010) shows that the market leaders achieved excellent results in all indicators. In our paper, we focused on analyzing the efficiency of banks based in the Slovak Republic with reference to the leaders of the banking market in 2009 and 2013. The purpose of the paper is to analyse the efficiency of banks in the Slovak Republic in 2009 and 2013 so that it is possible to find out which indicators are important for bank efficiency in terms of efficiency sustainability.

The basic procedure proposed by the Cinca \& Molinero (2001) is applied on the analysis of banks based in Slovakia. We applied a combination of DEA models and multi-criteria methods.

The multi-criteria methods were applied to efficiency scores expressed in models with different combinations of inputs and outputs, where each model has at least one input and at least one output. Our 
hypothesis will be formulated based on our previous research, literature research and analysis of the current status.

Our research (Grmanová, 2010), which focused on analyzing the efficiency of Czech and Slovak banks during the years 2006 to 2008 revealed a number of conclusions that will serve as the basis for our assumptions.

The bank with the largest value of input on a common banking market was efficient in a model with all inputs and outputs.

This bank was also efficient in all the models that had various combinations of inputs and outputs.

Weaknesses of banks in the analysed period were largely unchanged.

Based on our previous research, we expect that the largest bank in the Slovak banking market will be efficient in all the analysed models. Size of the banks is evaluated by indicators such as loans and advances to banks and customers. The largest bank in the Slovak banking market is Slovenská sporitelnáa, a.s.

As the Slovak banking market is relatively small, the three largest market leaders compete intensively and hence must make a significant effort to ensure efficiency of their activities. Therefore, we assume that the three largest banks in the model are efficient with all inputs and outputs. We will also assume that they achieve similar efficiency scores.

In Grmanová (2010) one of the results shown suggests that the strengths and weaknesses of banks have not changed significantly. That creates a presumption that the bank, which has at least similar values in efficiency scores in both years, will be the same.

In our research, based on previous research and based on the critical aspect of literature research we formulated these scientific hypotheses:

H1: The largest bank is efficient in all of the models with different combinations of inputs and outputs.

H2: The three largest banks in Slovakia are efficient in a model with all inputs and outputs.

H3: The three largest banks in the national banking market are the most similar in their efficiency scores for the models with different combinations of inputs and output (achieve the best results in all models).

To express the efficiency score we use the DEA models. DEA models are among the quantitative models aimed at expressing the relative efficiency scores of the analysed entities. The subjects analysed by DEA models are called Decision Making Units. DEA models fully embody the definition of efficiency. Decision Making Unit is to be rated as fully efficient on the basis of available evidence if and only if the performances of other Decision Making Units (DMUs) does not show that some of its inputs or outputs can be improved without worsening some of its other inputs or outputs (Bogetoft \& Otto, 2011; Cyrek, 2017; Stanickova, 2017). The main uses have been in evaluations of "management" and "program" efficiencies of DMUs of a not-for-profit variety such as schools, hospitals, etc (Banker et al., 1984).

Our research is based on variable returns from the scale. Returns from the scale according to production economy reflect the reaction of total product (output) while proportionally increasing of all inputs (Belás et al., 2010). The variable returns from scale assume that with a proportional change in all inputs there is not proportionally equal change in output. Basic radial models used in these assumptions are known as BCC models. On the basis of linear programming they transform multiple inputs into multiple outputs. They construct non-parametric data envelopment that is convex. DMUs that are part of the data envelopment are efficient if they have an efficiency score equal to 1 or $100 \%$. DMUs, which are not part of the data envelopment are inefficient. Efficiency scores of inefficient DMUs will be expressed by the efficiency scores relative to the envelopment of data (Grmanová, 2010).

In DEA models, the indicators are divided into two groups - the inputs and outputs. The inputs satisfy the minimization criterion, outputs the maximization criterion. In DEA models, the indicators are divided into two groups - the inputs and outputs. The inputs satisfy the minimization criterion, the outputs maximization criterion. One of the drawbacks of DEA analysis is that it is sensitive to a number of inputs and outputs with respect to number of units analysed (Kočišová, 2014).

The choice of indicators used in the DEA models in analyzing the efficiency of banks on the side of inputs and outputs is not clear-cut. In our analysis we apply an intermediate approach and indicators will be selected according to Stavárek \& Šulganová (2009) who used three inputs and two outputs. 13 banks are being assessed in our analysis. In determining the maximum number of inputs $m$ and outputs $r$ according to (Cooper et al., 2006) the following applies: 


$$
n \geq \max \{m r, 3(m+r)\} .
$$

Therefore, we used only two inputs and two outputs in our analysis. Inputs are liabilities to banks and customers and operating costs. Outputs are loans and advances to banks and customers and non-interest income. On the output side, capital is also used. The reason for this choice is a small number of banks in the Slovak Republic.

It is clear from this relationship, that we can use maximum 2 inputs and 2 outputs.

Inputs are:

1) liabilities to banks and customers

2) operating cost

Outputs are:

a) loans and advances to banks and customers

b) non-interest income.

In the input-oriented BCC model, we assumed to have n homogenous DMUs $U_{1}$ up to $U_{n}$ and we evaluate $r$ outputs and $m$ inputs. The input matrix was denoted as $\mathbf{X}=\left\{x_{i j}, i=1 \ldots m, j=1 \ldots n\right\}$. The output matrix was denoted as $\mathbf{Y}=\left\{y_{i j}, i=1, \ldots, r, j=1, \ldots, n\right\}$.

Our goal will be to guess the efficiency score. The efficiency score $\theta_{q}$ means solving a task of linear programming.

Minimize

under conditions

$$
\begin{gathered}
z=\theta_{q}-\varepsilon\left(\mathbf{e}^{T} \mathbf{s}^{*}+\mathbf{e}^{T} \mathbf{s}^{-}\right), \\
\mathbf{X} \lambda+\mathbf{s}^{-}=\theta_{q} \mathbf{x}_{q}, \\
\mathbf{Y} \lambda-\mathbf{s}^{+}=\mathbf{y}_{q}, \\
\mathbf{e}^{T} \lambda=1, \\
\lambda, \mathbf{s}^{+}, \mathbf{s}^{-} \geq 0,
\end{gathered}
$$

where $\theta_{q}$ expresses the efficiency score of $U_{q}$ unit (Jablonský \& Dlouhý, 2004)

$\mathbf{s}^{+}, \mathbf{s}^{-}$are deviation variables, $\mathbf{s}^{+}$represents a vector of non-negative slack associated with the output inequalities, $\mathbf{S}^{-}$represents a vector of non-negative slack associated with the input inequalities (Charnes et al., 1978).

$\boldsymbol{\lambda}$ is weight matrix $\mathbf{e}^{T}=(1,1 . ., 1)$

$\varepsilon$ infinitesimal constant.

Model is known as dual input-oriented BCC model in the expert literature. Target values of inputs and outputs to reach efficiency can be obtained by one of the following ways

1) $\mathbf{x}_{q}{ }^{\prime}=\mathbf{X} \lambda^{*}, \quad \mathbf{y}_{q}{ }^{\prime}=\mathbf{Y} \lambda^{*}$,

where $\lambda^{*}$ is the vector of optimal weight values calculated by the model

2) $\mathbf{x}_{q}{ }^{\prime}=\theta_{q}^{*} \mathbf{x}_{q}-\mathbf{s}^{-*}, \quad \mathbf{y}_{q}{ }^{\prime}=\mathbf{y}_{q}+\mathbf{s}^{+^{*}}$,

where symbols denoted as * are vectors of optimal variable values in the input-oriented BCC model (Jablonský \& Dlouhý, 2004) .

In our analysis we build on ideas of Cinca \& Molinero (2001) and create models that will result from the combination of all inputs and outputs. In all models we calculate the efficiency score for all DMUs. By comparing the values of efficiency score of a particular DMU in various models, we can track what impact adding/removal of an input or output brings to its efficiency and from that it is possible to identify weaknesses and strengths of DMU. Efficiency scores in the individual models are considered variables and individual DMUs are considered cases. In the next step, it is possible to use any of the techniques to address the reduction of redundant information.

In contrast to the principal component analysis, the factor analysis explains the correlation between the characters. Principal component analysis explains all variability between originator variables (Meloun et 
al., 2012), while factor analysis only variability that have shared variables (Rimarčík, 2007). In our analysis we focus on the variability that has shared variables and we use factor analysis, which allows to discover the hidden (i.e. latent) variables, i.e. the common factors.

When performing factor analysis initially we standardize all variables. Using factor analysis we create new variables (principal components), which are a linear combinations of original variables and are mutually uncorrelated. The first principal component expresses the greatest amount of information of the original variables. The second major component expresses the greatest amount of information of the original variables that were not picked in the first component, etc.

The output of factor analysis is the estimate of the values of the factor loads and estimate of factor scores. Load factor variables (saturations) reflect the correlation between variables and factors. From the values of factor loads it is possible for each factor to determine the group of variables that correlate most closely with it (Nábělková \& Hitka, 2007). Estimate of the factor score is an estimate of the values that obtain factors of individual objects. In case of weak correlation with most of the original variables, the interpretation is made impossible. The solution is the rotation of factors. There are several rotation techniques. It is recommended to use those that provide the simplest interpretation.

To determine the number of factors several techniques are used. In our analysis we use the threshold value of eigenvalues. Only those elements are selected that have value greater than 1 . In our analysis we use the method of principal components. The factors have zero mean value and unit variance. Factor score is a combined measure of each factor. It is expressed for each object.

We used cluster analysis to analyse similarity in efficiency scores. Cluster analyses are one of the possibilities available to exploit the information contained in multi-dimensional comparisons using the differentiation of sets into several relatively unified sets of clusters (Zámečník, 2015). Cluster analysis is grouped subjects into groups - clusters - based on their similarities and differences. The distance between the objects is expressed by various ways. The most frequently used measure is Euclidean distance (Rimarčík, 2007). For an m-dimensional space, the Euclidean distance $d_{A B}$ between $A=x_{1}, x_{2}, x_{3}, \ldots, x_{m}$ and $B=y_{1}, y_{2}, y_{3}, \ldots, y_{m}$ will express

$$
d_{A B}=\sqrt{\sum_{k=1}^{m}\left(y_{k}-x_{k}\right)^{2}}
$$

We express procedure clustering with Euclidean distance. For linking clusters we used the method Single linkage (Nearest neighbour), where the distance between two clusters is determined as the distance between the two closest members.

\section{EMPIRICAL RESULTS AND DISCUSSION}

At the outset of the analysis, we expressed descriptive statistics for inputs and outputs and compared their variability by coefficient of variation. The values of descriptive statistics are presented in Table 1 . The greatest arithmetic average value had liabilities to banks and customers. The arithmetic average was influenced mainly by large values of a small number of banks. The greatest variability expressed by the coefficient of variation showed non-interest income. The lowest variability showed loans and advances to banks and customers.

The largest indicator - loans and advances to banks and customers and non-interest income was attributed to Slovenská sporitelňa, a.s., Tatra banka, a.s. and V̌̌eobecná úverová banka, a.s. These three banks are considered to be leaders in the banking market.

In the next step, we expressed the efficiency score in BCC models of the thirteen banks in nine models. The efficiency scores results are shown in Table 2. The columns characterize inputs used and outputs. For example, a column $12 \mathrm{~b}$ indicates the inputs, which were used 1) liabilities to banks and customers and 2) operating costs and second output b) non-interest income. 
Descriptive statistics of analysed indicators in 2009

\begin{tabular}{|l|c|c|c|c|}
\hline & $\begin{array}{c}\text { Arithmetic average in } \\
\text { thousand EUR }\end{array}$ & $\begin{array}{c}\text { Median in } \\
\text { thousand EUR }\end{array}$ & $\begin{array}{c}\text { Standard } \\
\text { deviation }\end{array}$ & $\begin{array}{c}\text { Coefficient of } \\
\text { variation in \% }\end{array}$ \\
\hline $\begin{array}{l}\text { Loans and advances to } \\
\text { banks and customers }\end{array}$ & 2345358 & 1084170 & 2636600 & 112.4 \\
\hline Non-interest income & 36576 & 14804 & 45648 & 124.8 \\
\hline $\begin{array}{l}\text { Liabilities to banks and } \\
\text { customers }\end{array}$ & 2784411 & 1678720 & 3157781 & 113.4 \\
\hline Operating costs & 84274 & 39950 & 103422 & 122.7 \\
\hline
\end{tabular}

Source: own workings using annual reports and Statistica software

In 2009, seven banks were efficient, assessed using model with two inputs and two outputs. These were: Slovenská sporitel’ňa, a.s., ČSOB stavebná sporitelňna, a.s., Všeobecná úverová banka, a.s., Tatra banka, a.s., Prvá stavebná sporitel’ňa, a.s., Československá obchodná banka, a.s. and Slovenská záručná a rozvojová banka, a.s.

From the values of estimate of efficiency scores of banks with all the nine models used for the analysis and efficient in model with all inputs and outputs, there are following conclusions:

- All three banks, which we consider to be leaders in the banking market, have been efficient in a model with two inputs and two outputs.

- In all the models applied, ČSOB stavebná sporitel’ňa, a.s and Slovenská sporitel’̌na, a.s. were efficient.

- Slovenská záručná a rozvojová banka, a.s. had relatively low levels of efficiency scores in the models $2 \mathrm{a}, 2 \mathrm{~b}$ and $2 \mathrm{ab}$. The efficiency score ranges from 0.24 to 0.37 . In these models, the first input 1 / liabilities to banks and customers are not included. According to Cinca \& Molinero (2001) and Zhu (1998) may be noted: Slovenská záručná a rozvojová banka, a.s. only had a good performance with respect to the ratios that measure the input utilization by the first input.

- Československá obchodná banka, a.s., had lower levels in the models $1 \mathrm{a}, 1 \mathrm{~b}$ and $1 \mathrm{ab}$. In these models, the second input 2 / operating cost is not included.

Part of our analysis was the application of the factor analysis. At the outset, we have expressed the correlation matrix. The values are shown in Table 3. The minimum absolute value of the correlation coefficient $(0.29)$ was in case of $2 \mathrm{a}$ and $1 \mathrm{ab}$.

Table 2

Efficiency scores in nine BCC models of bank with the domicile in the Slovak Republic in 2009

\begin{tabular}{|l|l|l|l|l|l|l|l|l|l|l|}
\hline $\begin{array}{l}\text { Rank of } \\
\text { banks }\end{array}$ & & $12 \mathrm{ab}$ & $1 \mathrm{ab}$ & $2 \mathrm{ab}$ & $12 \mathrm{a}$ & $12 \mathrm{~b}$ & $1 \mathrm{a}$ & $1 \mathrm{~b}$ & $2 \mathrm{a}$ & $2 \mathrm{~b}$ \\
\hline 1. & $\begin{array}{l}\text { Československá obchodná } \\
\text { banka, a.s. }\end{array}$ & 1.00 & 0.79 & 1.00 & 1.00 & 0.88 & 0.79 & 0.64 & 1.00 & 0.88 \\
\hline 2. & $\begin{array}{l}\text { ČSOB stavebná } \\
\text { sporitel’na, a.s. }\end{array}$ & 1.00 & 1.00 & 1.00 & 1.00 & 1.00 & 1.00 & 1.00 & 1.00 & 1.00 \\
\hline 3. & OTP banka Slovensko, a.s. & 0.91 & 0.91 & 0.35 & 0.90 & 0.76 & 0.90 & 0.76 & 0.35 & 0.31 \\
\hline 4. & Poštová banka, a.s. & 0.76 & 0.76 & 0.18 & 0.37 & 0.76 & 0.37 & 0.76 & 0.10 & 0.18 \\
\hline 5. & Prima banka Slovensko, a.s. & 0.86 & 0.86 & 0.48 & 0.86 & 0.42 & 0.86 & 0.41 & 0.48 & 0.26 \\
\hline 6. & Privatbanka, a.s. & 0.77 & 0.44 & 0.77 & 0.77 & 0.66 & 0.41 & 0.40 & 0.77 & 0.66 \\
\hline 7. & Prvá stavebná sporitelňna, a.s. & 1.00 & 1.00 & 1.00 & 1.00 & 1.00 & 0.99 & 0.85 & 1.00 & 1.00 \\
\hline
\end{tabular}




\begin{tabular}{|c|l|c|c|c|c|c|c|c|c|c|}
\hline 8. & Sberbank Slovensko, a.s. & 0.75 & 0.75 & 0.34 & 0.74 & 0.63 & 0.74 & 0.63 & 0.34 & 0.30 \\
\hline 9. & Slovenská sporitel’ňa, a.s. & 1.00 & 1.00 & 1.00 & 1.00 & 1.00 & 1.00 & 1.00 & 1.00 & 1.00 \\
\hline 10. & $\begin{array}{l}\text { Slovenská záručná a } \\
\text { rozvojová banka, a.s. }\end{array}$ & 1.00 & 1.00 & 0.37 & 1.00 & 0.93 & 1.00 & 0.93 & 0.37 & 0.24 \\
\hline 11. & Tatra banka, a.s. & 1.00 & 1.00 & 1.00 & 1.00 & 0.84 & 1.00 & 0.84 & 1.00 & 0.73 \\
\hline 12. & $\begin{array}{l}\text { Všeobecná úverová } \\
\text { banka, a.s. }\end{array}$ & 1.00 & 1.00 & 1.00 & 0.92 & 1.00 & 0.85 & 1.00 & 0.91 & 1.00 \\
\hline 13. & $\begin{array}{l}\text { Wüstenrot stavebná } \\
\text { sporitel'na, a.s. }\end{array}$ & 0.97 & 0.95 & 0.75 & 0.95 & 0.88 & 0.65 & 0.88 & 0.75 & 0.70 \\
\hline
\end{tabular}

Source: own workings using annual reports and EMS software

Highlighted correlations are significant at the level of significance of 0.05. Meloun et al. (2012) argued that if there is no sufficient number of correlation coefficients exceeding the value of 0.30 , the factor analysis does not work. Simultaneously, when there are real factors in data, partial correlations will be low. The correlation matrix shows a clear data structure. Only two eigenvalues had value greater than or equal to 1. Therefore, we choose the number of factors 2 . They explain cumulatively over $84.37 \%$ of the total variance. The first common factor explains $66.07 \%$ of the variance contained in the 9 monitored variables (models), the second factor explains $18.30 \%$. The amount of eigenvalues and their cumulative frequency are shown in Table 4. The chosen method of extracting factors was the method of principal components. The load factors of both factors are listed in Table 5. To simplify the factor structure we used Varimax rotation.

Table 3

Correlation matrix derived from models for 2009 (standardize variables)

\begin{tabular}{|l|c|c|c|c|c|c|c|c|c|}
\hline & $12 \mathrm{ab}$ & $1 \mathrm{ab}$ & $2 \mathrm{ab}$ & $12 \mathrm{a}$ & $12 \mathrm{~b}$ & $1 \mathrm{a}$ & $1 \mathrm{~b}$ & $2 \mathrm{a}$ & $2 \mathrm{~b}$ \\
\hline $12 \mathrm{ab}$ & 1.00 & $\mathbf{0 . 7 9}$ & $\mathbf{0 . 6 8}$ & $\mathbf{0 . 8 4}$ & $\mathbf{0 . 7 6}$ & $\mathbf{0 . 7 7}$ & $\mathbf{0 . 6 9}$ & $\mathbf{0 . 6 9}$ & $\mathbf{0 . 6 5}$ \\
\hline $1 \mathrm{ab}$ & $\mathbf{0 . 7 9}$ & 1.00 & 0.30 & $\mathbf{0 . 5 6}$ & $\mathbf{0 . 6 0}$ & $\mathbf{0 . 8 0}$ & $\mathbf{0 . 8 1}$ & 0.29 & 0.31 \\
\hline $2 \mathrm{ab}$ & $\mathbf{0 . 6 8}$ & 0.30 & 1.00 & $\mathbf{0 . 6 7}$ & $\mathbf{0 . 5 9}$ & 0.41 & 0.35 & $\mathbf{1 . 0 0}$ & $\mathbf{0 . 9 6}$ \\
\hline $12 \mathrm{a}$ & $\mathbf{0 . 8 4}$ & $\mathbf{0 . 5 6}$ & $\mathbf{0 . 6 7}$ & 1.00 & 0.47 & $\mathbf{0 . 8 1}$ & 0.37 & $\mathbf{0 . 7 1}$ & $\mathbf{0 . 5 9}$ \\
\hline $12 \mathrm{~b}$ & $\mathbf{0 . 7 6}$ & $\mathbf{0 . 6 0}$ & $\mathbf{0 . 5 9}$ & 0.47 & 1.00 & 0.43 & $\mathbf{0 . 8 8}$ & $\mathbf{0 . 5 7}$ & $\mathbf{0 . 7 0}$ \\
\hline $1 \mathrm{a}$ & $\mathbf{0 . 7 7}$ & $\mathbf{0 . 8 0}$ & 0.41 & $\mathbf{0 . 8 1}$ & 0.43 & 1.00 & 0.52 & 0.44 & 0.36 \\
\hline $1 \mathrm{~b}$ & $\mathbf{0 . 6 9}$ & $\mathbf{0 . 8 1}$ & 0.35 & 0.37 & $\mathbf{0 . 8 8}$ & 0.52 & 1.00 & 0.32 & 0.46 \\
\hline $2 \mathrm{a}$ & $\mathbf{0 . 6 9}$ & 0.29 & $\mathbf{1 . 0 0}$ & $\mathbf{0 . 7 1}$ & $\mathbf{0 . 5 7}$ & 0.44 & 0.32 & 1.00 & $\mathbf{0 . 9 5}$ \\
\hline $2 \mathrm{~b}$ & $\mathbf{0 . 6 5}$ & 0.31 & $\mathbf{0 . 9 6}$ & $\mathbf{0 . 5 9}$ & $\mathbf{0 . 7 0}$ & 0.36 & 0.46 & $\mathbf{0 . 9 5}$ & 1.00 \\
\hline
\end{tabular}

Source: own workings

Table 4

Eigenvalues derived from models for 2009

\begin{tabular}{|l|c|c|c|}
\hline & Eigenvalue & \% of total & Cumulative frequency in $\%$ \\
\hline 1 & 5.9462 & 66.0683 & 66.0683 \\
\hline 2 & 1.6473 & 18.3028 & 84.3712 \\
\hline
\end{tabular}

Source: own working using Statistica software 
Load factors derived from models for 2009 (Varimax rotation)

\begin{tabular}{|l|l|l|}
\hline & Factor 1 & Factor 2 \\
\hline $12 \mathrm{ab}$ & 0.559267 & 0.775274 \\
\hline $1 \mathrm{ab}$ & 0.098078 & 0.955755 \\
\hline $2 \mathrm{ab}$ & 0.974315 & 0.185916 \\
\hline $12 \mathrm{a}$ & 0.615292 & 0.558912 \\
\hline $12 \mathrm{~b}$ & 0.503156 & 0.657145 \\
\hline $1 \mathrm{a}$ & 0.266681 & 0.803332 \\
\hline $1 \mathrm{~b}$ & 0.190759 & 0.850113 \\
\hline $2 \mathrm{a}$ & 0.975827 & 0.184881 \\
\hline $2 \mathrm{~b}$ & 0.941262 & 0.220860 \\
\hline
\end{tabular}

Source: own workings in Statistica software

Table 6

Factor score derived from models for 2009

\begin{tabular}{|l|c|c|}
\hline & Factor 1 & Factor 2 \\
\hline Československá obchodná banka, a.s. & 1.13428 & -0.53239 \\
\hline ČSOB stavebná sporitel’ňa, a.s. & 0.79064 & 0.73266 \\
\hline OTP banka Slovensko, a.s. & -1.09927 & 0.49144 \\
\hline Poštová banka, a.s. & -1.71286 & -0.73929 \\
\hline Prima banka Slovensko, a.s. & -0.75895 & -0.64495 \\
\hline Privatbanka, a.s. & 0.77943 & -2.48903 \\
\hline Prvá stavebná sporitel’ňa, a.s. & 0.87654 & 0.50842 \\
\hline Sberbank Slovensko, a.s. & -1.04016 & -0.67851 \\
\hline Slovenská sporitel’ňa, a.s. & 0.79064 & 0.73266 \\
\hline Slovenská záručná a rozvojová banka, a.s. & -1.19771 & 1.39861 \\
\hline Tatra banka, a.s. & 0.58256 & 0.46964 \\
\hline Všeobecná úverová banka, a.s. & 0.69934 & 0.55749 \\
\hline Wüstenrot stavebná sporitel’ňa, a.s. & 0.15554 & 0.19325 \\
\hline
\end{tabular}

Source: own workings using Statistica software

Part of factor analysis is an expression of the factor score. This will allow us to determine the similarity between objects. Its values are given in Table 6.

Next step, we expressed the Euclidean distances. The most similar values of factor score were recorded among Slovenská sporitel'ňa, a.s. and ČSOB stavebná sporitel'ňa, a.s. The second Euclidean distance have Tatra banka, a.s. and Všeobecná úverová banka, a.s. The least similar values of factor scores was Privatbanka, a.s. The values of Euclidean distance of connections are shown in Graph 1. 


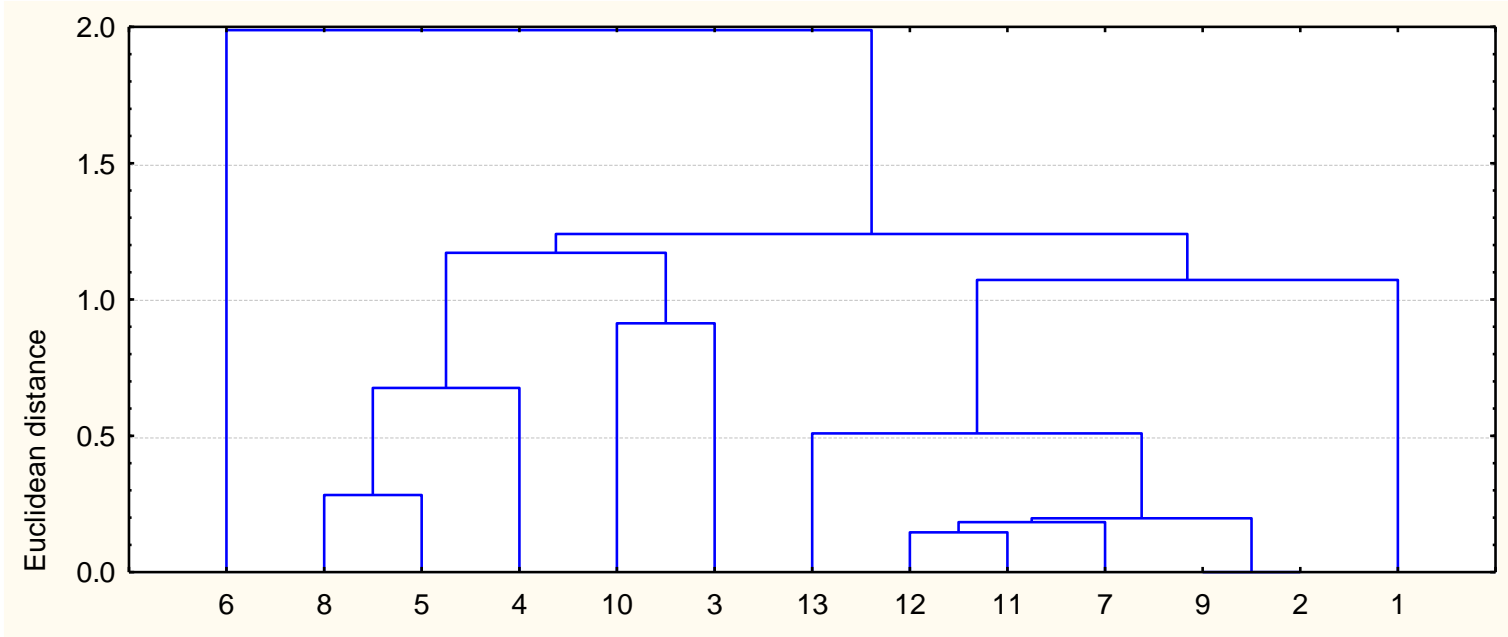

Graph 1. Euclidean distance for connection in 2009

Source: own workings using Statistica software

Factor score is used to express similarities through a cluster analysis. The banks having a negative factor score in the first factor have low efficiency values in $2 \mathrm{a}$ and $2 \mathrm{~b}$ models.

To compare changes over time, we expressed the values of thirteen banks in nine models in 2013. At the outset of the analysis, we expressed descriptive statistics for inputs and outputs. The values of descriptive statistics of inputs and outputs in 2013 are shown in Table 7. The maximum value of arithmetic average showed liabilities to banks and customers.

The greatest variability expressed by the coefficient of variation showed non-interest income. The lowest variability had liabilities to banks and customers. The biggest value of indicator loans and advances to banks and customers, similar to 2009, showed Slovenská sporitelňa, a.s., Tatra banka, a.s., and Všeobecná úverová banka, a.s. The difference between their values, however significantly decreased compared to the values in 2009 .

Table 7

Descriptive statistics of analysed indicators in 2013

\begin{tabular}{|l|c|c|c|c|}
\hline & $\begin{array}{c}\text { Arithmetic } \\
\text { average in } \\
\text { thousand EUR }\end{array}$ & $\begin{array}{c}\text { Median in } \\
\text { thousand } \\
\text { EUR }\end{array}$ & $\begin{array}{c}\text { Standard } \\
\text { deviation }\end{array}$ & $\begin{array}{c}\text { Coefficient of } \\
\text { variation in \% }\end{array}$ \\
\hline $\begin{array}{l}\text { Loans and advances to banks and } \\
\text { customers }\end{array}$ & 2694752 & 1611191 & 3082990 & 114.4 \\
\hline Non-interest income & 44514 & 16206 & 53643 & 120.5 \\
\hline Liabilities to banks and customers & 3115698 & 1689620 & 3255309 & 104.5 \\
\hline Operating costs & 87856 & 41430 & 98741 & 112.4 \\
\hline
\end{tabular}

Source: own workings using annual reports and Statistica software

Shown in Table 8 are the results of the efficiency scores for thirteen banks for 2013 domiciled in Slovakia. 
The values of efficiency scores in nine BCC models in 2013 for banks

\begin{tabular}{|c|c|c|c|c|c|c|c|c|c|}
\hline & $12 \mathrm{ab}$ & $1 \mathrm{ab}$ & $2 \mathrm{ab}$ & $12 \mathrm{a}$ & $12 \mathrm{~b}$ & $1 \mathrm{a}$ & $1 \mathrm{~b}$ & $2 \mathrm{a}$ & $2 \mathrm{~b}$ \\
\hline $\begin{array}{l}\text { Československá obchodná } \\
\text { banka, a.s. }\end{array}$ & 0.81 & 0.81 & 0.57 & 0.81 & 0.76 & 0.81 & 0.76 & 0.53 & 0.57 \\
\hline $\begin{array}{l}\text { ČSOB stavebná } \\
\text { sporitel’̌na, a.s. }\end{array}$ & 1.00 & 1.00 & 1.00 & 1.00 & 1.00 & 0.83 & 1.00 & 1.00 & 1.00 \\
\hline $\begin{array}{l}\text { OTP banka Slovensko, } \\
\text { a.s. }\end{array}$ & 0.69 & 0.69 & 0.41 & 0.16 & 0.69 & 0.14 & 0.69 & 0.13 & 0.41 \\
\hline Poštová banka, a.s. & 0.87 & 0.75 & 0.83 & 0.64 & 0.87 & 0.61 & 0.75 & 0.42 & 0.83 \\
\hline $\begin{array}{l}\text { Prima banka Slovensko, } \\
\text { a.s. }\end{array}$ & 0.75 & 0.68 & 0.52 & 0.73 & 0.69 & 0.68 & 0.61 & 0.47 & 0.52 \\
\hline Privatbanka, a.s. & 0.98 & 0.83 & 0.87 & 0.53 & 0.98 & 0.30 & 0.83 & 0.53 & 0.87 \\
\hline $\begin{array}{l}\text { Prvá stavebná } \\
\text { sporitel’̌na, a.s. }\end{array}$ & 1.00 & 0.88 & 1.00 & 1.00 & 1.00 & 0.88 & 0.63 & 1.00 & 1.00 \\
\hline $\begin{array}{l}\text { Sberbank Slovensko, } \\
\text { a.s. }\end{array}$ & 0.88 & 0.85 & 0.49 & 0.88 & 0.55 & 0.85 & 0.52 & 0.49 & 0.41 \\
\hline $\begin{array}{l}\text { Slovenská sporitel'ňa, } \\
\text { a.s. }\end{array}$ & 1.00 & 1.00 & 1.00 & 1.00 & 1.00 & 1.00 & 1.00 & 1.00 & 1.00 \\
\hline $\begin{array}{l}\text { Slovenská záručná a } \\
\text { rozvojová banka, a.s. }\end{array}$ & 1.00 & 1.00 & 0.76 & 1.00 & 1.00 & 1.00 & 1.00 & 0.76 & 0.53 \\
\hline Tatra banka, a.s. & 1.00 & 1.00 & 1.00 & 1.00 & 1.00 & 1.00 & 1.00 & 1.00 & 1.00 \\
\hline $\begin{array}{l}\text { Všeobecná úverová } \\
\text { banka, a.s. }\end{array}$ & 1.00 & 1.00 & 1.00 & 1.00 & 1.00 & 1.00 & 0.97 & 1.00 & 1.00 \\
\hline $\begin{array}{l}\text { Wüstenrot stavebná } \\
\text { sporitel’na, a. s. }\end{array}$ & 0.70 & 0.65 & 0.70 & 0.69 & 0.70 & 0.47 & 0.64 & 0.68 & 0.70 \\
\hline
\end{tabular}

Source: own working based on annual reports, processed in EMS software

In 2013, using the model with two inputs and two outputs, six banks were efficient. They were all the same banks that were efficient in 2009, except Československá obchodná banka, a.s.. From the values estimating the efficiency scores of banks in the territory of Slovakia in 2013 in the nine models, following conclusions can be drawn:

- Slovenská sporitelnna, a.s. a Tatra banka, a.s were efficient in all models.

- The first three largest banks were efficient in a model with two inputs and two outputs.

- Slovenská záručná a rozvojová banka, a.s. had relatively low levels of the efficiency scores in the models $2 \mathrm{a}, 2 \mathrm{~b}$ and $2 \mathrm{ab}$. Efficiency score ranges from 0.53 to 0.76 . In these models, the first input $1 /$ liabilities to banks and customers is not included. According to Cinca \& Molinero (2001) and Zhu (1998) it may be noted: Slovenská záručná a rozvojová banka, a.s. only had a good performance with respect to the ratios that measure the input utilization by the first input.

- Československá obchodná banka, a.s. had relatively low levels of the efficiency scores in the models $2 \mathrm{a}, 2 \mathrm{~b}$ and $2 \mathrm{ab}$. In these models, the first input $1 /$ liabilities to banks and customers is not included. Československá obchodná banka, a.s. only had a good performance with respect to the ratios that measure the input utilization by the first input.

- Prvá stavebná sporitelňna, a.s. had relatively low levels of the efficiency scores in the models 1a, $1 \mathrm{~b}$ and $1 \mathrm{ab}$. Prvá stavebná sporitelňa, a.s. only had a good performance with respect to the ratios that measure the input utilization by the second input.

In the next part of the study we applied factor analysis on the efficiency scores of thirteen banks in nine models. The correlation matrix expressed by the efficiency scores of the nine models of data from 2013 is in Table 9. The smallest absolute value of the correlation coefficient (0.41) was for the pair 1a and $2 \mathrm{~b}$. 
Correlation matrix derived from models for 2013 (standardize variables)

\begin{tabular}{|l|c|c|c|c|c|c|c|c|c|}
\hline & $12 \mathrm{ab}$ & $1 \mathrm{ab}$ & $2 \mathrm{ab}$ & $12 \mathrm{a}$ & $12 \mathrm{~b}$ & $1 \mathrm{a}$ & $1 \mathrm{~b}$ & $2 \mathrm{a}$ & $2 \mathrm{~b}$ \\
\hline $12 \mathrm{ab}$ & 1.00 & $\mathbf{0 . 9 1}$ & $\mathbf{0 . 8 3}$ & $\mathbf{0 . 7 1}$ & $\mathbf{0 . 8 3}$ & $\mathbf{0 . 6 6}$ & $\mathbf{0 . 6 8}$ & $\mathbf{0 . 7 6}$ & $\mathbf{0 . 7 0}$ \\
\hline $1 \mathrm{ab}$ & $\mathbf{0 . 9 1}$ & 1.00 & $\mathbf{0 . 7 1}$ & $\mathbf{0 . 7 6}$ & $\mathbf{0 . 7 4}$ & $\mathbf{0 . 7 7}$ & $\mathbf{0 . 8 0}$ & $\mathbf{0 . 7 9}$ & $\mathbf{0 . 5 7}$ \\
\hline $2 \mathrm{ab}$ & $\mathbf{0 . 8 3}$ & $\mathbf{0 . 7 1}$ & 1.00 & $\mathbf{0 . 6 2}$ & $\mathbf{0 . 9 0}$ & 0.51 & $\mathbf{0 . 6 8}$ & $\mathbf{0 . 8 6}$ & $\mathbf{0 . 9 6}$ \\
\hline $12 \mathrm{a}$ & $\mathbf{0 . 7 1}$ & $\mathbf{0 . 7 6}$ & $\mathbf{0 . 6 2}$ & 1.00 & 0.49 & $\mathbf{0 . 9 5}$ & 0.44 & $\mathbf{0 . 8 7}$ & 0.50 \\
\hline $12 \mathrm{~b}$ & $\mathbf{0 . 8 3}$ & $\mathbf{0 . 7 4}$ & $\mathbf{0 . 9 0}$ & 0.49 & 1.00 & 0.43 & $\mathbf{0 . 8 1}$ & $\mathbf{0 . 7 3}$ & $\mathbf{0 . 8 2}$ \\
\hline $1 \mathrm{a}$ & $\mathbf{0 . 6 6}$ & $\mathbf{0 . 7 7}$ & 0.51 & $\mathbf{0 . 9 5}$ & 0.43 & 1.00 & 0.46 & $\mathbf{0 . 7 7}$ & 0.38 \\
\hline $1 \mathrm{~b}$ & $\mathbf{0 . 6 8}$ & $\mathbf{0 . 8 0}$ & $\mathbf{0 . 6 8}$ & 0.44 & $\mathbf{0 . 8 1}$ & 0.46 & 1.00 & $\mathbf{0 . 6 1}$ & $\mathbf{0 . 5 8}$ \\
\hline $2 \mathrm{a}$ & $\mathbf{0 . 7 6}$ & $\mathbf{0 . 7 9}$ & $\mathbf{0 . 8 6}$ & $\mathbf{0 . 8 7}$ & $\mathbf{0 . 7 3}$ & $\mathbf{0 . 7 7}$ & $\mathbf{0 . 6 1}$ & 1.00 & $\mathbf{0 . 8 0}$ \\
\hline $2 \mathrm{~b}$ & $\mathbf{0 . 7 0}$ & $\mathbf{0 . 5 7}$ & $\mathbf{0 . 9 6}$ & 0.50 & $\mathbf{0 . 8 2}$ & 0.38 & $\mathbf{0 . 5 8}$ & $\mathbf{0 . 8 0}$ & 1.00 \\
\hline
\end{tabular}

Source: own workings in Statistica software

Highlighted correlations are significant on the level of significance of 0.05 . The correlation matrix shows a clear data structure.

Table 10

Eigenvalue derived from models for 2013

\begin{tabular}{|l|c|c|c|}
\hline & Eigenvalue & \% of total & Cumulative frequency in $\%$ \\
\hline 1 & 6.6800 & 74.2226 & 74.2226 \\
\hline 2 & 1.1988 & 13.3202 & 87.5428 \\
\hline
\end{tabular}

Source: own workings in Statistica software

The values of eigenvalues are shown in Table 10. Only two eigenvalues had a value greater than or equal to 1 . As number of factors we choose 2 . These two factors explain cumulatively over $87.54 \%$ of the total variance. The first common factor explains $74.22 \%$ of the variance contained in the 9 monitored variables, the second factor explaining $13.32 \%$. The chosen method for extracting factors was the method of principal components. The load factor of the two factors is in Table 11.

The values of Euclidean distance of banks are shown in Graph 2. Most similar levels of factor score were shown for the Slovenská sporitel’ňa, a.s., Tatra banka, a.s. and Všeobecná úverová banka, a.s. In both analysed years Slovenská sporitel’ňa, a.s. reached the top results. Comparable results reached ČSOB stavebná sporitel'ňa, a.s. in 2009 and Tatra banka, a.s. in 2013. The least similar in the efficiency scores was OTP banka Slovensko, a.s.

Table 11

The load factor derived from models for 2013 (Varimax rotation)

\begin{tabular}{|l|l|l|}
\hline & Factor 1 & Factor 2 \\
\hline $12 \mathrm{ab}$ & 0.711764 & 0.580131 \\
\hline $1 \mathrm{ab}$ & 0.597860 & 0.703992 \\
\hline $2 \mathrm{ab}$ & 0.897835 & 0.360742 \\
\hline $12 \mathrm{a}$ & 0.276890 & 0.940606 \\
\hline $12 \mathrm{~b}$ & 0.929725 & 0.259573 \\
\hline $1 \mathrm{a}$ & 0.177990 & 0.966107 \\
\hline $1 \mathrm{~b}$ & 0.762489 & 0.308039 \\
\hline $2 \mathrm{a}$ & 0.627399 & 0.697211 \\
\hline $2 \mathrm{~b}$ & 0.884370 & 0.223768 \\
\hline
\end{tabular}

Source: own workings using Statistica software 
The values of factor scores are shown in Table 12. The banks having a negative factor score in the second factor, have low efficiency values in 1 a model.

Table 12

Factor scores derived from models for 2013

\begin{tabular}{|l|c|c|}
\hline & Factor 1 & Factor 2 \\
\hline Československá obchodná banka, a.s. & -0.92750 & 0.28171 \\
\hline ČSOB stavebná sporitel’na, a.s. & 1.01540 & 0.40590 \\
\hline OTP banka Slovensko, a.s. & -0.63880 & -2.09519 \\
\hline Poštová banka, a.s. & 0.25758 & -0.86490 \\
\hline Prima banka Slovensko, a.s. & -1.28800 & -0.11206 \\
\hline Privatbanka, a.s. & 1.15877 & -1.52207 \\
\hline Prvá stavebná sporitel’ňa, a.s. & 0.47599 & 0.50886 \\
\hline Sberbank Slovensko, a.s. & 1.96683 & 1.03375 \\
\hline Slovenská sporitel'ňa, a.s. & 0.86613 & 0.68857 \\
\hline Slovenská záručná a rozvojová banka, a.s. & -0.05533 & 1.00129 \\
\hline Tatra banka, a.s. & 0.86613 & 0.68857 \\
\hline Všeobecná úverová banka, a.s. & 0.82755 & 0.70350 \\
\hline Wüstenrot stavebná sporitel’ňa, a.s. & -0.59108 & -0.71794 \\
\hline
\end{tabular}

Source: own workings using Statistica software

From the analysis of data in 2009 and 2013, we can therefore conclude that hypotheses $\mathrm{H}_{1}$ and $\mathrm{H}_{2}$ have been confirmed. Slovenská sporitelňa, a.s. was efficient in all models with different combinations of inputs and outputs. The three largest banks in the Slovak national banking market have been efficient in a model with two inputs and two outputs in both analysed years. Out of the three banks, only Slovenská sporitel’na, a.s. was efficient in all the models. The hypothesis $\mathrm{H}_{3}$ was however not confirmed. The three largest banks in the national market in 2009 were not very similar when comparing the efficiency scores in models with different combinations of inputs and outputs. Similar to Slovenská sporitel'ňa, a.s. in 2009 were the smaller banks such as ČSOB stavebná sporitel’na, a.s.. In 2013, however, was the most similar trio of the largest banks, Slovenská sporitel’ňa, a.s., Tatra banka, a.s. and Všeobecná úverová banka, a.s.

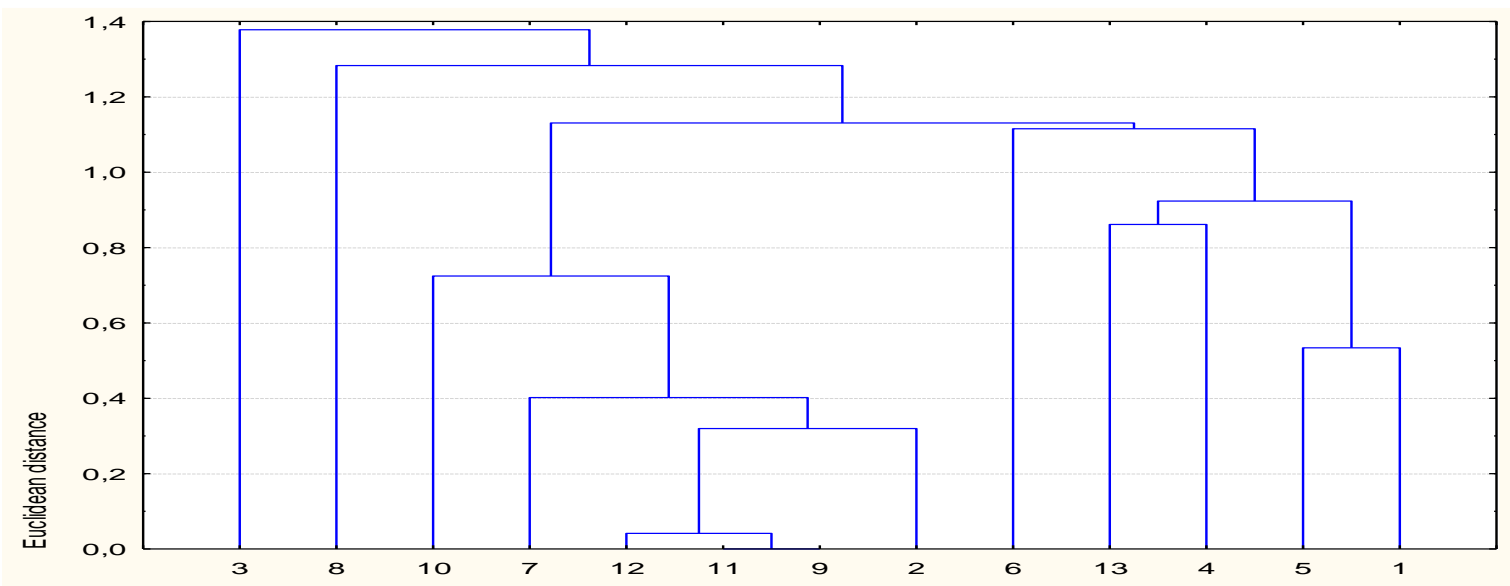

Graph 2. Euclidean distance for connection in 2013

Source: own workings using Statistica software 
The efficiency analysis shows that Slovenská sporitel’na, a.s. achieved excellent results. The research on bank efficiency over the years 2001-2005 by Stavárek \& Šulganová (2009) did not show best efficiency in Slovenská sporitel'ňa, a.s. In 2001 Slovenská sporitel’ňa, a.s. achieved even the lowest efficiency level. The biggest positive change, however, was achieved in the years under analysis. It seems that Slovenská sporitel'ňa, a.s. underwent positive changes over the years 2001-2005 and ranks among the most efficient banks in the market. It follows from our analysis that the three biggest banks were also efficient ones. The research conducted by Stavárek \& Šulganová (2009) showed that the three big banks were not among efficient banks. Všeobecná úverová banka, a.s. took even the ninth or tenth position among thirteen banks. It seems, however, that the bank also underwent significant and positive changes.

\section{CONCLUSION}

The purpose of the paper was to analyse the efficiency of banks in the Slovak Republic in 2009 and 2013 so that it is possible to find out which indicators are important for the efficient bank in terms of efficiency sustainability. Therefore, after the input-output analysis we determined the efficiency scores in all of our created the models. From the comparison we derived important indicators for the efficient bank.

In 2009, seven banks were efficient; in 2013 six banks were efficient. All banks that were efficient in 2013 were also efficient in 2009. The three largest banks in the Slovak national banking market were efficient in both analysed years. Slovenská sporitel’ňa, a.s. was efficient in all models with different combinations of inputs and outputs.

Most similar values of factor scores in 2009 showed Slovenská sporitel’ňa, a.s., ČSOB stavebná sporitel’ňa, a.s. In 2013, Slovenská sporitel'ňa, a.s. showed most similar values with Tatra banka a.s. and V̌̌eobecná úverová banka, a.s.

In 2009 , in the period of economic crisis, was the similarity between the three major leaders in the banking market in the efficiency scores lower than in 2013. The smaller similarity in 2009 may have resulted from significant changes in the external environment and bigger bank's ability to react more flexibly. Small banks can adapt to large fluctuations more flexibly. In a balanced environment, the leaders in the banking market show closer results.

Our research showed that the largest bank was efficient in all models and therefore we confirmed the conclusion of our study Grmanová (2010). However, we could not confirm that the three largest banks would show similar efficiency scores in all the models.

Slovenská záručná a rozvojová banka, a.s. only had a good performance with respect to the ratios that measure the input utilization by the liabilities to banks and customers in both years. Prvá stavebná sporitel'ňa, a.s. had a good performance with respect to the ratios that measure the input utilization by the operating cost in 2013. Československá obchodná banka, a.s. only had a good performance with respect to the ratios that measure the input utilization by the second input 2) operating cost in 2009 and by the first input - 1) liabilities to banks and customers in 2013.

Of course, our research has several limitations.

1) One of the main limitations is relatively small number of banks in the Slovak Republic. A small number of banks affect the number of inputs and outputs that can be used to estimate the level of efficiency. Therefore, it would be useful for further research aimed at a common Czech and Slovak banking market. Such an extension would allow using even more inputs and outputs and thus increase the number of analysed parameters.

2) Time frame of two years should be extended to a continuous period, which would have begun before the crisis period and would allow the analysis of changes in the bank's efficiency during the times of crisis.

Other research possibilities are in using Two-stage DEA models in analyzing the efficiency of banks. The research focused on the application of Two-stage DEA models could lead to interesting results and contribute both to extending the theoretical aspects of the issue and secondly to deepened practical conclusions with the possibility of generalization.

The contribution of our analysis, in addition to the comparison of the relative efficiency of the banks, is the application of process that results in the provision of information about important indicators for the efficient bank in terms of efficiency sustainability. 
This approach can be beneficial for practice. Its application may lead to improved management and performance of banks and thus can be the basis for some generalizations on the given subject.

\section{REFERENCES}

Banker, R.D., Charnes, A., \& Cooper, W.W. (1984). Some Models for Estimating Technical and Scale Inefficiencies in Data Envelopment Analysis. Management Science, $\quad 30(9)$, doi: https://dx.doi.org/10.1287/mnsc.30.9.1078

Banks. (2009). Annual Report 2009.

Banks. (2013). Annual Report 2013.

Belás, J. et al. (2010). Management of Commercial Banks, Banking Transactions and Operations. Žilina: GEORG.

Berger, A.N., \& Humprey, D.B. (1997). Efficiency of Financial Institutions: International Survey and Directions for Future Research. European Journal of Operational Research, 98(2), 175-212. Retrieved July 7, 2015, from: http://www.knowledge.wharton.upenn.edu/papers n/67.pdf. doi: 10.2139/ssrn.2140.

Bogetoft, P., \& Otto, L. (2011). Benchmarking with DEA, SFA, and R. New York: Springer. doi: https://dx.doi.org/10.1007/978-1-4419-7961-2

Chandrasekaran, R., \& Gopal, R.M. (2013). Evaluation of Efficiency and Benchmarking Commercial Banks in India: A Combined PCA and DEA Approach. International Journal of Statistika and Mathematika, 8(2) 60-70.

Chansarn, S. (2008). The Relative Efficiency of Commercial Banks in Thailand: DEA Approach. International Research Journal of Finance and Economics, (18), 53-68.

Charnes, A., Cooper, W., \& Rhodes, E. (1978). Measuring the Efficiency of Decision-Making Units. European Journal of Operational Research, 2(4), 429-444. doi: https://dx.doi.org/10.1016/0377-2217(78)90138-8

Cinca, C.S., \& Molinero, C.M. (2001). Selecting DEA Specifications and Ranking Units via PCA. Discussion Papers in Management. University of Southampton. Retrieved June 5, 2016, from: https://eprints.soton.ac.uk/35727/

Cipovová, E., \& Belás, J. (2012). Assessment of Credit Risk Approaches in Relation with Competitiveness Increase of the Banking Sector. Journal of Competitiveness, 4(2), 69-84.

Cooper, W.W., Seiford, M.L., \& Tone, K. (2006). Introduction to Data Envelopment Analysis and Its Uses. Boston: Springer.

Cyrek, M. (2017). Social efficiency of employment in three sectors - a comparison of Polish regions. Equilibrium. Quarterly Journal of Economics and Economic Policy, 12(3), 417-432. doi: https://doi.org/10.24136/eq.v12i3.22

Gasiorowski, J. (2016). Managing security in electronic banking - legal and organisational aspects. Forum Scientiae Oeconomia, 4(1), 123-136.

Grmanová, E. (2010). Evaluation of the Efficiency of Commercial Insurance and Banks by Data Envelopment Analysis Model. Trenčín: TnUAD.

Jablonský, J., \& Dlouhý, M. (2004). Models of Evaluating the Efficiency of Production Units. Praha: Professional Publishing.

Jemric', I., \& Vujčic', B. (2002). Efficiency of Banks in Croatia: A DEA Approach. Working Papers. Croatian National Bank. doi: https://dx.doi.org/10.1057/ces.2002.13

Ključnikov, A., \& Popesko, B. (2017). Export and its Financing in The SME Segment. Case Study From Slovakia. Journal of Competitiveness, 9(1), pp.20-35, doi:10.7441/joc.2017.01.02

Knápková, A., Homolka, L., \& Pavelková, D. (2014). Utilization of Balanced Scorecard and the Effect of its Use on the Financial Performance of Companies in the Czech Republic. E+M Ekonómie a Management, 17(2), 146-160. doi: https://dx.doi.org/10.15240/tul/001/2014-2-011.

Kočišová, K. (2014). The Use of Payment Cards and Efficiency of Banks. E+M Ekonómie a Management, 17(1), 121 138. doi: https://dx.doi.org/10.15240/tul/001/2014-1-010

Kordostami, S., Amirteimoori, A., \& Masoumzadeh, A. (2011). Evaluating the Efficiency of DMUs with PCA and an Application in Real Data Set of Iranian Banks. International Journal of Industrial Mathematic, 3(4), 251-258.

Kubiszewska, K. (2017). Banking concentration in the Baltic and Western Balkan states - selected issues. Oeconomia Copernicana, 8(1), 65-82. doi: https://doi.org/10.24136/oc.v8i1.5

Luciano, E., \& Regis, L. (2007). Bank Efficiency and Banking Sector Development: The Case of Italy. Working Paper Series. International Centre for Economic Research. Retrieved July 7, 2015, from http://servizi.sme.unito.it/icer repec/RePEc/icr/wp2007/ICERwp5-07.pdf

Meloun, M., Militký, J., \& Hill, M. (2012). Statistical Analysis of Multidimensional Data in the Examples. Praha: ACADEMIA. Nábělková, E., \& Hitka, M. (2007). Choice of Suitable Proceeding in Statistical Analysis of Motivation Factors in a Company. Human Resources Management \& Ergonomics, (1). Retrieved June 15, 2015, from: http://frcatel.fri.uniza.sk/hrme/files/2007/2007 1 06.pdf

NBS. (2015). The list of Banks Established in Slovakia. Retrieved June 15, 2015, from: https://www.nbs.sk 
Nuhiu, A., Hoti, A., \& Bektashi, M. (2017). Determinants of commercial banks profitability through analysis of financial performance indicators: evidence from Kosovo, Business: Theory and Practice, 18, 160-170. doi: https://doi.org/10.3846/btp.2017.017

Palečková, I. (2015). Efficiency Change in Banking Sectors of Visegrad Countries. In Proceedings of the 7th International Scientific Conference Finance and the Performance of Firms in Science, Education and Practice, 1153-1168. Zlín: Tomas Bata University of Zlín.

Puriwat, W., \& Tripopsakul, S. (2017). The impact of e-service quality on customer satisfaction and loyalty in mobile banking usage: Case study of Thailand. Polish Journal of Management Studies, 15(2), 183-193. doi:10.17512/pjms.2017.15.2.17

Rimarčík, M. (2007). Statistics for Practice. Custom edition.

Saha, A., \& Ravisankar, T.S. (2000). Rating of Indian Commercial Banks: A DEA Approach. European Journal of Operational Research, 124(1), 187-203. doi: https://dx.doi.org/10.1016/S0377-2217(99)00167-8.

Sealeay, C.W., \& Lindley, J.T. (1977). Inputs, Outputs and a Theory of Production and Cost at Depository Financial Institutions. Journal of Finance, 32(8), 1251-1266. doi: http://dx.doi.org/10.1111/j.1540-6261.1977.tb03324.x

Sherman, D.H., \& Gold, F. (1985). Bank Branch Operating Efficiency: Evaluation with Data Envelopment Analysis. Journal of Banking \& Finance, 9(3), 297-315. doi: http://dx.doi.org/10.1016/0378-4266(85)90025-1

Stanickova, M. (2017). Can the implementation of the Europe 2020 Strategy goals be efficient? The challenge for achieving social equality in the European Union. Equilibrium. Quarterly Journal of Economics and Economic Policy, 12(3), 383-398. doi: https://doi.org/10.24136/eq.v12i3.20

Stavárek, D. (2005). Restructuring of the Banking Sector and the Efficiency of Banks in the Countries of the Visegrad Group. Opava: Silesian University in Opava.

Stavárek, D., \& Šulganová, J. (2009). Analysis of the Efficiency of Slovak Banks Using Stochastic Frontier Approach. Economic Review, 12(1), 27-33. doi: https://doi.org/10.7327/cerei.2009.03.03

Vivas, A.L., Pastor, J.T., \& Pastor, J.M. (2002). An Efficiency Comparison of European Banking Systems Operating under Different Environmental Conditions. Journal of Productivity Analysis, 18(1), 59-77.

Wheelock, D.C., \& Wilson, P.W. (1995). Evaluating the Efficiency of Commercial Banks: Does Our View of What Banks Do Matter?. Review, Federal Reserve Bank of St. Louis, 77(4), 39-52.

Zámečník, R. (2015). Human Resources Controlling as a Tool for Measuring Human Resources Key Performance Indicators. In Proceedings of the 7th International Scientific Conference Finance and the Performance of Firms in Science, Education and Practice. Zlín: Tomas Bata University of Zlín.

Zhu, J. (1998). Data Envelopment Analysis vs. Principal Component Analysis: an Illustration Study of Economic Performance of Chinese cities. European Journal of Operational Research, 111(1), 50-61. doi: https://dx.doi.org/10.1016/S0377-2217(97)00321-4 